\section{Multitactic Preplant Soil Fumigation with Allyl Isothiocyanate in Cut Flowers and Strawberry}

\author{
Mark Hoffmann ${ }^{1}$, Husein A. Ajwa ${ }^{2}$, Becky B. Westerdahl ${ }^{3}$, \\ Steven T. Koike ${ }^{4}$, Mike Stanghellini ${ }^{4}$, Cheryl Wilen ${ }^{5}$, \\ and Steven A. Fennimore ${ }^{2}$
}

\begin{abstract}
AdDITIONAL INDEX WORDS. combined fumigation, soil disinfestation, soil-borne
\end{abstract} pest management

Summary. Allyl isothiocyanate (AITC) is a glucosinolate produced in cruciferous plant species. AITC is known to act as a pesticide on microorganisms, insects, and weeds. Synthetic AITC is registered as a biopesticide for agricultural soil treatment use in the United States and elsewhere in the world. Although a potent pesticide, reports on the weed and pathogen control efficacy of synthetic AITC applied as soil disinfectant are highly variable. Due to the low vapor pressure of AITC, questions remain as to whether pest and weed control efficacy can be improved by combining it with other chemicals. The objective of this study was to assess the control efficacy of AITC stand-alone applications vs. applications, in which AITC was combined with the standard-fumigants chloropicrin, 1,3-dichloropicrin, and methyl isothiocyanate. Two shank-applied on-farm field trials were conducted in cut flower [delphinium (Delphinium elatum), ranunculus (Ranunculus asiaticus)] fields, and two drip tape applied field trials in strawberry (Fragaria $\times$ ananassa) fields in California. Weed pressure, weed seed viability, nematode survival, and pathogen survival of Pythium ultimum, fusarium wilt (Fusarium oxysporum), and verticillium wilt (Verticillium dabliae) were assessed. Cumulative yearly yield of marketable fruit was assessed in the strawberry field trials. The results of this study show that the use of AITC as a stand-alone treatment provided no consistent weed or pathogen control efficacy. However, our results also indicate that shank and drip applied multitactic fumigation approaches with AITC can efficiently control soil-borne diseases and weeds. These findings have potential implications, especially in those areas where certain fumigants are restricted due to regulations and/or availability.

I ntensive fruit, ornamental, and vegetable production systems in the United States and elsewhere in the world rely on preplant soil fumigation to control soil-borne pathogens, pests, and weeds. These include strawberry (Fragaria $\times$ ananassa) and cut flower production systems. For decades, methyl bromide (MB) was the prevalent soil fumigant in the United States. Although MB is still used for quarantine purposes and to treat perishable goods, the use of $\mathrm{MB}$ as a preplant soil fumigant is restricted to use in strawberry nurseries. As of May 2019, 1,3-dichloropicrin (1,3D), chloropicrin (Pic), dimethyl disulfide (DMDS), dazomet, and methyl isothiocyanate (MITC) have been the prevalent fumigants used for cropping systems in the United States (Atwood and Paisley-Jones, 2017). Those fumigants are heavily restricted due to regulations and availability (U.S. Environmental Protection Agency, 2010), which leads frequently to situations in which fields remain nontreated and often are not planted, due to the expected substantial yield losses (Xu et al., 2017).

Several tools are being developed with the aim to expand the spectrum Nonchemical alternatives such as steam (Fennimore et al., 2014; Hoffmann et al., 2016), anaerobic soil disinfestation (Shennan et al., 2018), or soil solarization (Daugovish et al., 2016) are among those investigated. Chemical and biological alternatives such as plant of reliable soil disinfestation methods. residues and antimicrobial metabolites are active areas of research (Mazzola et al., 2017). Among the natural antimicrobial metabolites, several glucosinates have shown the potential to act as potent pesticides. Glucosinates are secondary plant metabolites that are mainly found in seeds of plants of the mustard (Brassicaceae) and caper (Capparaceae) families (Fahey et al., 2001; Maldonado et al., 2015).

Breakdown products of glucosinolates are known to contribute to plant defenses against pests and pathogens (Grubb and Abel, 2006). Allyl isothiocyanate (AITC) is a glucosinolate breakdown product with well-documented pesticide activity (Lin et al., 2000; Wu et al., 2009); it is used for postharvest pest and pathogen control on processed food and fresh produce (Maldonado et al., 2015). AITC is also shown to have proven activity against soil-borne nematodes (Wood et al., 2017), soilborne fungal pathogens (Neubauer et al., 2015), and insects (de Souza et al., 2018), and it reduces the viability of weed seeds and weed seed germination at high application rates (Bangarwa and Norsworthy, 2014). AITC can be used for preplant soil disinfestation by the incorporation of plant residues containing AITC, the planting of AITCproducing plants such as mustards of the genus Brassica, and the application of commercially available synthetic AITC (Dominus; Isagro USA, Morrisville, NC) via shank or drip application (Isagro USA, 2015).

Although those treatments can lead to the control of specific pathogens and nematodes, the efficacy of organic material containing AITC under field conditions is highly variable and depends on the soil structure, quality of plant residues, and

\begin{tabular}{lllc}
\hline $\begin{array}{l}\text { Units } \\
\text { To convert U.S. to SI, } \\
\text { multiply by }\end{array}$ & U.S. unit & SI unit & $\begin{array}{l}\text { To convert SI to U.S., } \\
\text { multiply by }\end{array}$ \\
\hline 0.4047 & $\mathrm{acre}(\mathrm{s})$ & $\mathrm{ha}$ & 2.4711 \\
29.5735 & $\mathrm{fl} \mathrm{oz}$ & $\mathrm{mL}$ & 0.0338 \\
0.3048 & $\mathrm{ft}$ & $\mathrm{m}$ & 3.2808 \\
9.3540 & gal $/ \mathrm{acre}$ & $\mathrm{L} \cdot \mathrm{ha}^{-1}$ & 0.1069 \\
2.54 & inch(es) & $\mathrm{cm}$ & 0.3937 \\
16.3871 & inch & $\mathrm{cm}^{3}$ & 0.0610 \\
1.1209 & lb/acre & $\mathrm{kg} \cdot \mathrm{ha}^{-1}$ & 0.8922 \\
0.1333 & $\mathrm{~mm} \mathrm{Hg}$ & $\mathrm{kPa}$ & 7.5006 \\
28.3495 & $\mathrm{oz}$ & $\mathrm{g}$ & 0.0353 \\
0.001 & $\mathrm{ppm}$ & $\mathrm{g} \cdot \mathrm{L}^{-1}$ & 1000 \\
1 & $\mathrm{ppm}$ & $\mathrm{mg} \cdot \mathrm{L}^{-1}$ & 1 \\
1 & $\mathrm{ppm}$ & $\mu \mathrm{g} \cdot \mathrm{mL}^{-1}$ & 1 \\
0.001 & $\mathrm{ppm}$ & $\mathrm{mL} \cdot \mathrm{L}^{-1}$ & 1000 \\
$\left({ }^{\circ} \mathrm{F}-32\right) \div 1.8$ & ${ }^{\circ} \mathrm{F}$ & ${ }^{\circ} \mathrm{C}$ & $\left({ }^{\circ} \mathrm{C} \times 1.8\right)+32$
\end{tabular}


environmental factors (Mazzola et al., 2017). The application of synthetic AITC has led to inconclusive results on weed, nematode, and pathogen control efficacy under field conditions (Bangarwa and Norsworthy, 2015, 2016; Vallad and Boyd, 2013).

Several chemical, physical, and biological factors determine the efficacy of a soil-applied pesticide (Munnecke and Van Gundy, 1979). Soil temperature, soil moisture, microbial activity, the ratio between mixed materials, and vapor pressure of a substance are factors that determine the fate and efficacy of a pesticide in soil. Soil fumigants are substances with high vapor pressure, and this helps them to disperse through the soil. Vapor pressure describes the rate at which a chemical leaves the liquid phase at a certain temperature. The higher the vapor pressure of a substance, the more rapid the substance can dissolve and be re-absorbed in the soil-air-water space. Soil water content plays an important role because commonly used fumigants are dissolved into the soil-air space and later re-absorbed by water surrounding soil particles. Fumigants also need a certain soil-air space to guarantee free movement through the soil body (Munnecke and Van Gundy, 1979).

Received for publication 5 Apr. 2019. Accepted for publication 24 Jan. 2020.

Published online 5 March 2020.

${ }^{1}$ North Carolina State University, Department of Horticultural Science, Kilgore Hall, 2721 Founders Drive, Raleigh, NC 27695

${ }^{2}$ University of California, Davis, Department of Plant Sciences, 1636 East Alisal Street, Salinas, CA 93905

${ }^{3}$ University of California, Davis, Department of Entomology and Nematology, 1 Shields Avenue, Davis, CA 95616

${ }^{4}$ TriCal Inc., 8100 Arroyo Circle, Gilroy, CA 95020

${ }^{5}$ University of California Agriculture and Natural Resources, Orange County, 9335 Hazard Way, Suite 201, San Diego, CA 92123

Funds for this study were provided by the U.S. Department of Agriculture (USDA)-National Institute of Food and Agriculture (NIFA) Methyl Bromide Transition Program. We thank Mike Mellano of Mellano and Co., Jose Garcia of Gemma Berry, John Rachuy, Alicia Scholler, Madeleine Wainscott, Adrian Bravo, and Julio Corona for their help with laboratory and field trials. We also thank Frank Martin of USDA-Agricultural Research Service (ARS) Salinas, Jayesh Samtani of Virginia Tech, and Emma Volk of North Carolina State University for their valuable input regarding the manuscript.

M.H. is the corresponding author. E-mail: mark. hoffmann@ncsu.edu.

This is an open access article distributed under the CC BY-NC-ND license (https://creativecommons.org/ licenses/by-nc-nd/4.0/).

https://doi.org/10.21273/HORTTECH04362-19
Commonly used fumigants such as $1,3-\mathrm{D}[43 \mathrm{~mm}$ mercury $(\mathrm{Hg})$ at $20^{\circ} \mathrm{C}$ ], $\operatorname{MITC}\left(21 \mathrm{~mm} \mathrm{Hg}\right.$ at $\left.20^{\circ} \mathrm{C}\right)$, and chloropicrin $(16.9 \mathrm{~mm} \mathrm{Hg}$ at $20{ }^{\circ} \mathrm{C}$ ) have relatively high vapor pressures compared with AITC. The low vapor pressure of AITC $(4 \mathrm{~mm}$ $\mathrm{Hg}$ at $20^{\circ} \mathrm{C}$ ) may be the reason for inconsistent results with soil-applied AITC on pathogens and weeds. Questions remain regarding whether the combination of AITC with pesticides with higher vapor pressure could increase the reliability and efficacy of AITC-based applications for soil disinfestation. The objective of this study was to evaluate the pathogen and weed control efficacy of AITC as a stand-alone treatment and combined with 1,3-D, Pic, and MITC.

\section{Materials and methods}

To evaluate weed and pathogen control efficacy of AITC alone and multitactic fumigant approaches in different cropping systems, four field trials were established in cut flower and strawberry production systems in California. Pic and 1,3-D (Pic+1,3-D) were applied as $56.6 \%$ Pic and $37.1 \%$ 1,3-D (v/v) (Pic-Clor 60; TriCal, Gilroy, CA), and MITC was applied as metam sodium (Vapam; AMVAC, Axis, AL). Two commercial cut flower field trials were established in Carlsbad, CA, and Oceanside, CA (both 2014 and 2015), and two commercial strawberry field trials were established in Watsonville, CA (2013-14) and Salinas, CA (201415). Weed and pathogen control data were recorded during all field trials.

\section{Cut flower field trials}

Experimental SETUP. Two onfarm cut flower fumigation field trials were conducted in 2014 and 2015 in Carlsbad, CA [delphinium (Delphinium elatum), ranunculus (Ranunculus asiaticus)] and Oceanside, CA (delphinium). Cut flower species were chosen due to the regional value of the acreage they represent. Fumigant application rates and fumigant application dates are shown in Table 1. All fumigants were shank-applied.

Field trial Carlsbad (201415). In Carlsbad, the following treatments were broadcast shank-applied on 2 Oct. 2014: 1) MB:Pic (29 gal/ acre); 2) Pic+l,3-D (29 gal/acre); 3) AITC $96.3 \%$ (40 gal/acre); 4) AITC
96.3\% (27 gal/acre) co-injected with Pic (14 gal/acre); and 5) nontreated control. Plots were $11 \mathrm{ft}$ wide and $160 \mathrm{ft}$ long. Each treatment was replicated three times. Fumigants were injected in the flat ground at a depth of 12 inches, with shanks spaced 30 inches apart. The total width of one pass was $11 \mathrm{ft}$. Fumigated soil was immediately covered with clear totally impermeable film (TIF), glued to a continuous sheet. Fumigants and TIF were applied by TriCal. TIF plastic was removed 21 $\mathrm{d}$ after fumigation and flowers were planted within 1 week after plastic removal. Soil samples to assess pathogen control were obtained after plastic removal. Weed densities were assessed once per month after plastic removal until the last flower harvest.

Field trial Oceanside (201415). In Oceanside, the following treatments were applied on 14 Nov. 2014: 1) Pic+1,3-D (29 gal/acre); 2) AITC (14 gal/acre) co-injected with Pic (27 gal/acre); and 3 ) nontreated control. Plots were $11 \mathrm{ft}$ wide and 120 $\mathrm{ft}$ long. Each treatment was replicated three times. Fumigants were injected and TIF was applied as described for Carlsbad. TIF plastic was removed 21 $\mathrm{d}$ after fumigation and flowers were planted within 1 week after plastic removal. Soil samples to assess pathogen control efficacy were taken after plastic removal. Weed densities were assessed once per month after plastic removal until final flower harvest.

Weed CONTROL. During all field trials, the weed densities were frequently assessed until crop growth did not allow subsequent weed counts. Weed densities were counted in four $5 \times 5$ - $\mathrm{ft}$ sample areas per replicate at monthly intervals. Weed densities are reported as number per acre of flower field.

Pathogen control. To evaluate the fumigant efficacy for Pythium ultimum and fusarium wilt (Fusarium oxysporum), mixed soils samples (depth, 6 inches) were obtained posttreatment. Five samples were combined to create one mixed sample taken from a $5 \times 5$-ft sample area. Four mixed soil samples were taken per treatment. The survival of $P$. ultimum was assessed using the wet plating method on semi-selective medium (Klose et al., 2007). Corn meal agar [17 g. $\mathrm{L}^{-1}$ (Sigma-Aldrich, St. Louis, MO)] was prepared and sterilized. 
Table 1. Fumigation treatments, methods of fumigant injection, application rates, and the date of application for all field trials in cut flower and strawberry cropping systems.

\begin{tabular}{|c|c|c|c|c|c|}
\hline Crop & Location & Treatment $^{\mathrm{z}}$ & Method $^{\mathrm{y}}$ & Rate (gal/acre) ${ }^{x}$ & Date of application $^{z}$ \\
\hline \multirow[t]{6}{*}{ Cut flowers } & \multirow[t]{5}{*}{ Carlsbad, CA } & Nontreated control & - & - & - \\
\hline & & MB:Pic 50:50 & Shank & 29 & 2 Oct. 2014 \\
\hline & & $\mathrm{Pic}+1,3-\mathrm{D}$ & Shank & 29 & 2 Oct. 2014 \\
\hline & & AITC & Shank & 40 & 2 Oct. 2014 \\
\hline & & AITC: Pic 66:34 & Shank & $27+14$ & 2 Oct. 2014 \\
\hline & Oceanside, CA & Nontreated control & - & - & - \\
\hline \multirow[t]{13}{*}{ Strawberry } & \multirow[t]{5}{*}{ Watsonville, CA } & Nontreated control & - & - & - \\
\hline & & $\mathrm{Pic}+1,3-\mathrm{D}$ & Drip & 29 & 11 Nov. 2013 \\
\hline & & AITC & Drip & 40 & 11 Nov. 2013 \\
\hline & & Pic+1,3-D f.b. AITC (low) & Drip & 10 f.b. 20 & 11 Nov. 2013 \\
\hline & & Pic +1,3-D f.b. AITC (high) & Drip & 14 f.b. 27 & 11 Nov. 2013 \\
\hline & \multirow[t]{8}{*}{ Salinas, CA } & Nontreated control & - & - & - \\
\hline & & AITC (high) & Drip & 40 & 11 Oct. 2014 \\
\hline & & \multirow[t]{2}{*}{ Pic $+1,3-D$ f.b. AITC } & \multirow[t]{2}{*}{ Drip } & \multirow[t]{2}{*}{20 f.b. 20} & 15 Oct. 2014 (AITC) \\
\hline & & & & & 11 Oct. $2014(\mathrm{Pic}+1,3-\mathrm{D})$ \\
\hline & & \multirow[t]{2}{*}{ MITC f.b. AITC } & \multirow[t]{2}{*}{ Drip } & \multirow[t]{2}{*}{31 f.b. 20} & 15 Oct. 2014 (AITC) \\
\hline & & & & & 15 Oct. 2014 (metam) \\
\hline & & \multirow[t]{2}{*}{ Pic $+1,3-D$ f.b. MITC } & \multirow[t]{2}{*}{ Drip } & \multirow[t]{2}{*}{20 f.b. 31} & 11 Oct. $2014(\mathrm{Pic}+1,3-\mathrm{D})$ \\
\hline & & & & & 15 Oct. 2014 (metam) \\
\hline
\end{tabular}

${ }_{\mathrm{z}} \mathrm{MB}=$ methyl bromide; Pic = chloropicrin; $1,3-\mathrm{D}=1,3$-dichloropropene; AITC $=$ allyl isothiocyanate; MITC = methyl isothiocyanate; f.b. = followed by; metam = metam sodium.

${ }^{\mathrm{y}}$ Shank = preplant shank application; drip = preplant application through drip line.

${ }^{\mathrm{x}} 1 \mathrm{gal} / \mathrm{acre}=9.3540 \mathrm{~L} \cdot \mathrm{ha}^{-1}$.

After sterilization, $1 \mathrm{~mL} \cdot \mathrm{L}^{-1}$ nonionic detergent (Tween 20; Thermo Fisher Scientific, Waltham, MA) was added; $25 \mu \mathrm{g} \cdot \mathrm{mL}^{-1}$ rose bengal (Thermo Fisher Scientific), $10 \mu \mathrm{g} \cdot \mathrm{mL}^{-1}$ rifampicin (Thermo Fisher Scientific), 25 $\mu \mathrm{g} \cdot \mathrm{mL}^{-1}$ ampicillin (Sigma-Aldrich), $5 \mu \mathrm{g} \cdot \mathrm{mL}^{-1}$ pimaricin (Sigma-Aldrich), and $40 \mu \mathrm{g} \cdot \mathrm{mL}^{-1}$ benomyl (SigmaAldrich) were added to the agar at $50{ }^{\circ} \mathrm{C}$. After cooling, 0.5 to $1 \mathrm{~g}$ of wet inoculum was spread (same dilution) on a total of five plates in three replicates. Plates were incubated at room temperature in the dark. $P$. ultimum colonies were counted during the first $2 \mathrm{~d}$ after plating. The mean propagules per gram of soil were calculated for all three replicates (Klose et al., 2007).

The effect of soil disinfestation on the survival of fusarium wilt was assessed according to Klose et al. (2007). In brief, air-dried soil samples were mixed and pulverized (mortar and pestle). The number of F. oxisporum propagules were determined by plating four replicates on modified Komada's medium (Komada, 1975). Propagule counts were combined and the colony-forming units (cfu) per gram of soil were calculated.

\section{Strawberry field trials}

Experimental SETup. Two strawberry fumigation field trials were conducted: one in Watsonville, CA (2013-14) and one in Salinas, CA (2014-15). Fumigant application rates and fumigant application dates are shown in Table 1. All fumigants were drip-applied using two drip lines per bed (10-inch emitter space, with each drip line 2 inches under the bed surface and 2 inches from the bed center). The total bed width was 52 inches (furrow to furrow). Beds were 8 inches high and 28 inches wide at the top. Beds were covered with black TIF plastic. The strawberry planting conformation comprised two rows per bed. Weed densities per planting hole were assessed in Salinas (201415) on a frequent basis between transplanting and the start of the harvest season. The survival of artificially introduced weed seeds was assessed during both trials. Pathogen and nematode survival were assessed in Salinas (2014-15).
Field TRIAL WatsonVILle (2013-14). A strawberry field trial was established in Watsonville, CA, with a commercial grower. The following treatments were installed: 1 ) Pic+1,3-D (29 gal/acre); 2) AITC (40 gal/acre); 3) Pic+1,3-D (10 gal/acre) followed by AITC [low (20 gal/acre)]; 4) Pic+1,3-D (14 gal/acre) followed by AITC [high (27 gal/acre)]; and 5) nontreated control. All treatments were established in four replicates each using a randomized complete block design. Each replicate covered a bed length of $10 \mathrm{ft}$, with 24 in buffer zones between replicates. 'Albion' strawberry plants were transplanted on 30 Nov. 2013. Treatments, application days and rates are shown in Table 1 . Yield was assessed in a sample area of 40 strawberry plants per replicate.

Field trial Salinas (201415). A strawberry field trial was established in Salinas, CA. Eight treatments were established in four replicates each, using a randomized complete block design: 1) MITC [low (31 gal/acre)]; 2) MITC [high (62 gal/acre)]; 3) AITC [low (20 
gal/acre)]; 4) AITC [high (40 gal/ acre)]; 5) Pic +1,3-D (20 gal/acre) followed by AITC (20 gal/acre); 6$)$ MITC (31 gal/acre) followed by AITC (20 gal/acre); 7) Pic+1,3-D (20 gal/acre) followed by MITC (31 gal/acre); and 8) nontreated control. All treatments were established in four replicates each using a randomized complete block design. Each replicate covered a bed length of $10 \mathrm{ft}$ with 24-inch buffer zones between replicates. 'Monterey' strawberry plants were transplanted on 17 Nov. 2014. Treatments, application days and rates are shown in Table 1 . Yield was assessed in a sample plot of 40 plants per replicate.

Weed control (Watsonville and Salinas). To evaluate the weed control efficacy of the treatments, the viability of artificially introduced weed seeds and tubers as well as the natural weed spectrum was assessed after treatments. Weed seeds of burning nettle (Urtica urens), common purslane [Portulaca oleracea (Salinas only)], common knotweed [Polygonum arenastrum (Salinas only)], shepherds purse [Capsella bursapastoris (Watsonville only)], annual bluegrass $[\mathrm{Poa}$ annua (Watsonville only)], and tubers of yellow nutsedge (Cyperus esculentus) were enclosed in seed bags (Delnet Delstar Technologies, Middletown, DE) and placed 6 inches deep in the center of the plots before treatment. Seed bags were produced as described by Hoffmann and Fennimore (2017). Fifty seeds of burning nettle, common knotweed, shepherds purse, and annual bluegrass and 25 yellow nutsedge tubers were place in a seed bag. Two bags per plot were placed 6 inches deep. All seed bags were recovered 2 weeks after treatment. The survival of the seeds was assessed by the tetrazolium test using $\mathrm{l} \mathrm{g} \cdot \mathrm{L}^{-1}(0.1 \% \mathrm{v} / \mathrm{v})$ tetrazolium tetrachloride (Sigma-Aldrich), as described by Baalbaki et al. (2009) and Cottrell (1947). Recovered yellow nutsedge tubers were placed in sand and grown under greenhouse conditions $\left(14 / 10 \mathrm{~h} \mathrm{light} / \mathrm{dark}, 18^{\circ} \mathrm{C}\right)$ for 4 weeks, and the number of sprouting tubers was counted. Seed viability is given as an average number of viable seeds per 25 seeds. Tuber sprouting rates are given as an average number of sprouted tubers per 10 tubers. In Salinas, the weed spectrum was assessed in the nonmulch-covered planting holes. Weeds were counted in monthly hand-weeding events for all treatments, including the nontreated control. The weeding areas per replicate were $4 \mathrm{ft}$ long and 27 inches wide (width of one strawberry bed).

Nematode control (Salinas ONLY). To evaluate nematode control, four bags per treatment containing citrus nematodes (Tylenchulus semipenetrans) were placed at 9- and 18 -inch depths, respectively (6 Oct. 2014). Citrus nematode samples were obtained from a citrus orchard in Glen County, CA. Small muslin bags (Forestry Suppliers, Jackson, MS) were filled with $50 \mathrm{~cm}^{3}$ of infested soil and tied with a plastic cord. Two bags per plot were buried belowground and recovered 14 $\mathrm{d}$ after treatment. The survival of citrus nematodes was assessed by analyzing any living nematodes after extraction with a modified Bearmann funnel system (Ayoub, 1977). Samples were kept at room temperature for $72 \mathrm{~h}$. Juvenile nematodes were counted in a 10 -mL aliquot from each sample using a microscope.

Pathogen control (Salinas ONLY). To evaluate fumigant efficacy for $P$. ultimum and verticillium wilt (Verticillium dabliae), two bags (Forestry Suppliers) per plot containing $P$. ultimum inoculum and $V$. dabliae inoculum were placed at 9- and 18-inch depths (6 Oct. 2014) and recovered $14 \mathrm{~d}$ after treatment. P. ultimum- and $V$. dabliae-infested soil were obtained from strawberry fields in Monterey County, CA. The survival of $P$. ultimum was assessed as previously described. The survival of $V$. dabliae was assessed using a dry plating method on Sorensens' +++10 semi-selective medium described by Kabir et al. (2004). In brief, two media were prepared and sterilized separately: 1) medium with $10 \mathrm{~g} \cdot \mathrm{L}^{-1}$ polygalacturonic acid [PGA (product no. 3889, Sigma-Aldrich)] and $2.4 \mathrm{~g} \cdot \mathrm{L}^{-1}(\mathrm{pH} 5.68)$ sodium hydroxide $(\mathrm{NaOH})$ pellets (Thermo Fisher Scientific); 2) and Sorensens' NP-10 semi-selective medium comprising $30 \mathrm{~g} \cdot \mathrm{L}^{-1}$ agar (Difco Bacto Agar; Carolina Biological, Burlington, NC), $2 \mathrm{~g} \cdot \mathrm{L}^{-1}$ potassium nitrate (Sigma-Aldrich), $2 \mathrm{~g} \cdot \mathrm{L}^{-1}$ monopotassium phosphate (Sigma-Aldrich), I $\mathrm{g} \cdot \mathrm{L}^{-1}$ potassium chloride (Thermo Fisher Scientific), $1 \mathrm{~mL} \cdot \mathrm{L}^{-1}$ magnesium sulfate heptahydrate (Thermo Fisher Scientific), and $1 \mathrm{~mL} \cdot \mathrm{L}^{-1}$ nonionic surfactant (Tergitol NP-10, Sigma-Aldrich). After autoclaving, both media were cooled to $50{ }^{\circ} \mathrm{C}$. The following antibiotics were added to Sorensens' $\mathrm{NP}-10$ at $50{ }^{\circ} \mathrm{C}: 100 \mathrm{mg} \cdot \mathrm{L}^{-1}$ chloramphencinol (Sigma-Aldrich), 100 $\mathrm{mg} \cdot \mathrm{L}^{-1}$ tetracycline (Sigma-Aldrich), and $100 \mathrm{mg} \cdot \mathrm{L}^{-1}$ streptomycin (SigmaAldrich). Both, Sorensens' NP-10 medium and PGA medium were mixed after adding antibiotics and poured immediately. The inoculum derived from $V$. dabliae bags was dried at room temperature for 2 weeks on a greenhouse bench. Dry inoculum was ground and $0.5 \mathrm{~g}$ was plated on a total of six NP-10PGA plates using two stages of a cascade impactor (Andersen Sampler, Atlanta, GA). Plates were incubated in the dark at room temperature for 3 weeks. Developed colonies of $V$. dabliae microsclerotia were counted under the microscope and miscrosclerotia per gram of soil were calculated.

Yield (Watsonville and Salinas). To assess the impact of fumigation treatments on strawberry yield, the weights of marketable fruits were measured at every harvest event from Apr. to Aug. 2014 (Watsonville) and from Apr. to Sept. 2015 (Salinas). Cumulative yields (pounds per acre) were calculated.

\section{Statistical analyses}

All data were analyzed using RStudio Desktop 1.1.442 with R 3.4.4. (RStudio, Boston, MA). Pathogen densities, weed seed viability, tuber germination, weed density data, and strawberry yield data were analyzed using an analysis of variance (fixed effect model III, $\alpha=0.05$ ). Adjunct Fisher's least significant difference post hoc tests $(\alpha=0.05)$ were performed to separate groups of significance, when appropriate. Beforehand, each group was tested for normal distribution [Shapiro-Wilk $(\alpha=0.05)]$.

\section{Results}

Cut flower trials. The AITC (40 gal/acre) stand-alone treatment did not control $P$. ultimum or the weeds in the Carlsbad field trial. MB:Pic and the Pic+1,3-D stand-alone treatments had significantly reduced pathogen levels and weed populations in Carlsbad (Table 2). However, the AITC (40 gal/acre) stand-alone treatment and the AITC (27 gal/acre) co-injected with Pic (14 gal/acre) 
treatment significantly reduced the $F$. oxysporum cfu per gram of soil, but not to the level of the MB:Pic and Pic+1,3$\mathrm{D}$ treatments. However, at the Oceanside cut flower field trial, AITC (14 gal/acre) co-injected with a higher amount of Pic (27 gal/acre) reduced fusarium wilt, P. ultimum, and weed populations significantly, similar to Pic+1,3-D (29 gal/acre) (Table 2).

WATSONVILLE STRAWBERRY TRIAL. Weed seed viability was significantly reduced in all treatments compared with the nontreated control. However, the viability of yellow nutsedge tubers was significantly higher with the AITC (40 gal/acre) and the Pic+1,3-D followed by AITC (low) multitactic treatment compared with the Pic $+1,3-\mathrm{D}$ (29 gal/acre) and the Pic+1,3-D followed by AITC (high) treatment (Table 4). Although higher rates of AITC can lead to reduced nutsedge viability (Bangarwa and Norsworthy, 2015), higher rates of $\mathrm{Pic}+1,3-\mathrm{D}$ led to increased weed control efficacy. The Pic+1,3-D followed by AITC (high) treatment reduced the viability of nutsedge tubers to the level of the stand-alone $\mathrm{Pic}+1,3-\mathrm{D}$ (29 gal/acre) treatment (Table 4). Cumulative marketable yields were not significantly affected by any fumigation treatments in Watsonville (Table 5 ).

SALINAS STRAWBERry trial. All treatments in the Salinas strawberry field trial reduced pathogen, nematode, and weed viability compared with the nontreated control (Table 3 ). Citrus nematode populations and P. ultimum cfu per gram of soil were reduced significantly in both soil depths (9 and 18 inches) after all treatments. No significant differences were found in the control efficacy of P. ultimum and levels of the citrus nematode between stand-alone and multitactic fumigation approaches in both depths. However, the number of verticillium wilt microsclerotia per gram of soil in the 9-inch depth was significantly higher with the AITC (40 gal/acre) treatment compared with all other treatments (Table 3 ).

Each treatment also significantly reduced the weed seed viability of burning nettle, knotweed, and common purslane and the tuber viability of yellow nutsedge compared with the nontreated control (Table 4). MITC (low and high) treatments resulted in greater reductions in seed viability of knotweed seed and yellow nutsedge tubers. AITC (low) reduced the viability of knotweed seed significantly, whereas AITC (high) and MITC followed by AITC reduced the sprouting activity of yellow nutsedge tubers (Table 4). However, the only treatment that lowered seed and tuber viability of all four tested species significantly was the multitactic treatment Pic+1,3-D followed by AITC. The yields of the AITC (high) standalone and MITC (low) stand-alone treatment were similar to the yields of the nontreated control (Table 5).

\section{Discussion}

AITC has well-documented bactericidal, fungicidal, insecticidal, and herbicidal activities and is frequently used as a food preservative (Guo et al., 2017; Lopes et al., 2017, 2018). It has been introduced to the U.S. market and elsewhere as a biofumigant (Isagro USA, 2015), and others have reported that preplant soil applications with AITC were effective for several pathogens and weeds under warm conditions in sandy soils (Rosskopf et al., 2017). However, several reports also indicated inconsistent or insufficient control efficacy of soil-applied AITC treatments. Bangarwa and Norsworthy (2015, 2016) found low AITC activity on yellow nutsedge and purple nutsedge (Cyperus rotundus). In our studies, the pest control efficacy of standalone AITC applications was investigated and compared with multitactic shank- and drip-applied applications in which AITC was combined with commonly used fumigants. Results showed that stand-alone drip or shank applications of AITC lead to inconsistent or no pathogen and weed control efficacy in strawberry and cut flower trials on the central coast and southern coast of California.

During shank-applied cut flower and in drip-applied strawberry field trials, AITC at $40 \mathrm{gal} /$ acre did not show effective control of all soilborne pathogens and only marginal weed control (Table 2-4). AITC (40 gal/acre) stand-alone treatments did not result in higher yields than the nontreated control in any of the strawberry field trials (Table 5). A $66 \%$ AITC (27 gal/acre) + 34\% Pic+ 1,3-D (14 gal/acre) shank-applied treatment in Carlsbad, CA, resulted in lower weed and pathogen control activity compared with a Pic $+1,3-\mathrm{D}$ stand-alone and MB:Pic (50:50) treatment (Table 2).

However, AITC combined with higher rates of $\mathrm{Pic}+1,3-\mathrm{D}$ or MITC could be the best option for use of AITC to reduce pathogen and weed populations and boost yields. In Oceanside, CA, shank-applied 34\% AITC (14

Table 2. Weed densities and survival of pathogens in cut flower field trials.

\begin{tabular}{|c|c|c|c|c|}
\hline Location & Treatment $^{\mathrm{z}}$ & $\begin{array}{l}\text { Weeds (1000 weeds/ } \\
\text { acre })^{\mathrm{y}}\end{array}$ & $\begin{array}{l}\text { Pytbium ultimum } \\
\text { (propagules/g) }^{\mathrm{y}}\end{array}$ & $\begin{array}{l}\text { Fusarium oxysporum } \\
(\mathrm{cfu} / \mathrm{g})^{\mathrm{y}}\end{array}$ \\
\hline \multirow[t]{4}{*}{ Carlsbad, CA } & Nontreated control & $52.6 \mathrm{ab}^{\mathrm{x}}$ & $39 \mathrm{~b}$ & $721 \mathrm{a}$ \\
\hline & $\mathrm{Pic}+1,3-\mathrm{D}$ & $1.5 \mathrm{c}$ & $0 \mathrm{c}$ & $0 \mathrm{c}$ \\
\hline & AITC & $61.7 \mathrm{a}$ & $80 \mathrm{a}$ & $47 \mathrm{~b}$ \\
\hline & AITC: Pic 66:34 & $30.6 \mathrm{abc}$ & $36 \mathrm{~b}$ & $38 \mathrm{~b}$ \\
\hline Oceanside, CA & AITC: Pic 34:66 & $0.56 \mathrm{~b}$ & $0 \mathrm{~b}$ & $424 \mathrm{~b}$ \\
\hline
\end{tabular}

${ }^{\mathrm{z}} \mathrm{MB}=$ methyl bromide: $\mathrm{Pic}=$ chloropicrin; $1,3-\mathrm{D}=1,3$-dichloropropene; $\mathrm{AITC}=$ allyl isothiocyanate.

${ }^{\mathrm{y}} 1000$ weeds $/$ acre $=2471.0538$ weeds $/ \mathrm{ha} ; \mathrm{l}$ propagule $/ \mathrm{g}=28.3495$ propagules $/ \mathrm{oz} ; \mathrm{l} \mathrm{cfu} / \mathrm{g}=28.3495 \mathrm{cfu} / \mathrm{oz}$

${ }^{x}$ Analysis of variance with adjunct Fisher's least significant difference test. Any two means within a row not followed by the same letter are statistically different at $P \leq 0.01$. 
Table 3. Weed densities and survival of pathogens and citrus nematodes in a strawberry field trial in Salinas, CA.

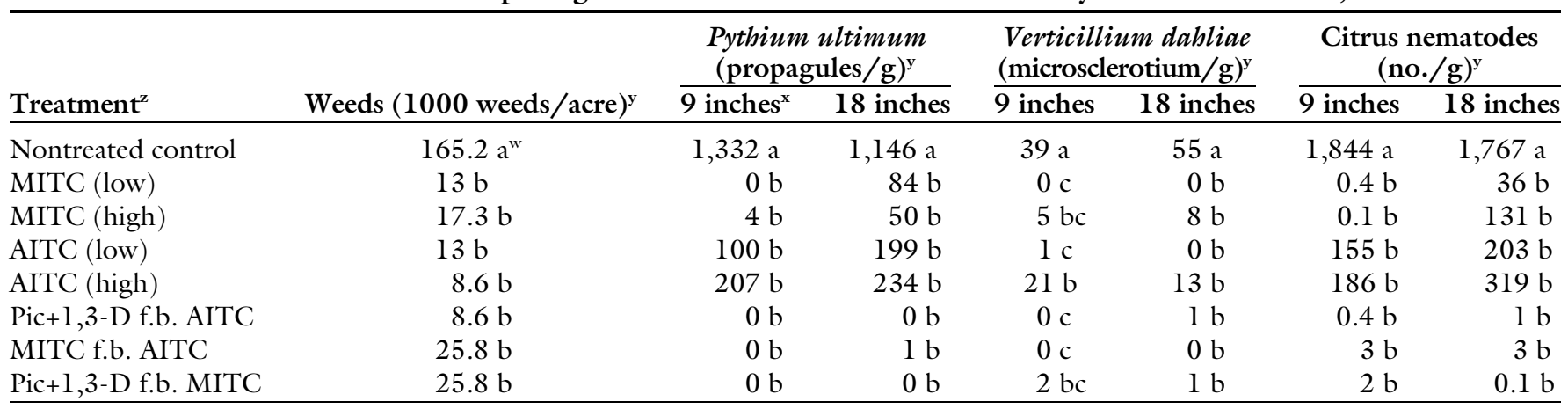

${ }^{\mathrm{z}} \mathrm{Pic}=$ chloropicrin; $1,3-\mathrm{D}=1,3$ dichloropropene; $\mathrm{AITC}=$ allyl isothiocyanate; MITC $=$ methyl isothiocyanate; f.b. = followed by.

${ }^{\mathrm{y}} 1000$ weeds $/$ acre $=2471.0538$ weeds $/$ ha; 1 propagule $/ \mathrm{g}=28.3495$ propagules $/ \mathrm{oz} ; 1$ microsclerotium $/ \mathrm{g}=28.3495$ microsclerotia $/$ oz; 1 nematode $/ \mathrm{g}=28.3495$ nematodes/oz.

${ }^{\mathrm{x}}$ Soil depth of sample; 1 inch $=2.54 \mathrm{~cm}$.

wAnalysis of variance with adjunct Fisher's least significant difference test. Any two means within a row not followed by the same letter are statistically different at $P \leq 0.01$.

Table 4. Weed propagule viability in strawberry field trials. Seed viability after treatment application of burning nettle, shepherds purse, annual bluegrass, common knotweed, and common purslane (after tetrazolium assay) and sprouting rates of yellow nutsedge tubers are shown.

\begin{tabular}{|c|c|c|c|c|c|c|c|}
\hline \multirow[b]{2}{*}{ Location } & \multirow[b]{2}{*}{ Treatment $^{\mathrm{z}}$} & $\begin{array}{c}\text { Burning } \\
\text { nettle }\end{array}$ & $\begin{array}{l}\text { Shepherds } \\
\text { purse }\end{array}$ & $\begin{array}{c}\text { Annual } \\
\text { bluegrass }\end{array}$ & $\begin{array}{l}\text { Common } \\
\text { knotweed }\end{array}$ & $\begin{array}{l}\text { Common } \\
\text { purslane }\end{array}$ & \multirow{2}{*}{$\begin{array}{c}\text { Yellow nutsedge } \\
\text { Sprouting rate (no. } \\
\text { sprouted/10 tubers) }\end{array}$} \\
\hline & & \multicolumn{5}{|c|}{ Viability (no. viable/25 seeds) } & \\
\hline \multirow[t]{3}{*}{$\begin{array}{l}\text { Watsonville, } \\
\text { CA }\end{array}$} & $\begin{array}{c}\text { Nontreated } \\
\text { control }\end{array}$ & $5.75 \mathrm{a}^{\mathrm{y}}$ & $1.75 \mathrm{a}$ & $5.5 \mathrm{a}$ & - & - & $8.6 \mathrm{a}$ \\
\hline & $\mathrm{Pic}+1,3-\mathrm{D}$ & $0 \mathrm{~b}$ & $0.5 \mathrm{ab}$ & $0.5 \mathrm{~b}$ & - & - & $0 \mathrm{c}$ \\
\hline & $\begin{array}{l}\text { Pic+1,3-D f.b. } \\
\text { AITC (high) }\end{array}$ & $0 \mathrm{~b}$ & $0 \mathrm{~b}$ & $0 \mathrm{~b}$ & - & - & $0 \mathrm{c}$ \\
\hline \multirow[t]{5}{*}{ Salinas, CA } & $\begin{array}{l}\text { Nontreated } \\
\text { control }\end{array}$ & $20.25 \mathrm{a}$ & - & - & $19.25 \mathrm{a}$ & $19.75 \mathrm{a}$ & $8.1 \mathrm{a}$ \\
\hline & MITC (low) & $4.25 \mathrm{c}$ & - & - & $0.75 \mathrm{c}$ & $1.5 \mathrm{~b}$ & $0.2 \mathrm{c}$ \\
\hline & $\begin{array}{l}\text { Pic }+1,3-\mathrm{D} \text { f.b. } \\
\text { AITC }\end{array}$ & $0.75 \mathrm{de}$ & - & - & $0.25 \mathrm{c}$ & $0.25 \mathrm{c}$ & $0.1 \mathrm{c}$ \\
\hline & MITC f.b. AITC & $8 \mathrm{~b}$ & - & - & $2 \mathrm{bc}$ & $1 \mathrm{bc}$ & $0.3 \mathrm{c}$ \\
\hline & $\begin{array}{l}\text { Pic+1,3-D f.b. } \\
\text { MITC }\end{array}$ & $0.5 \mathrm{e}$ & - & - & $1.25 \mathrm{bc}$ & $0.75 \mathrm{bc}$ & $0.1 \mathrm{c}$ \\
\hline
\end{tabular}

${ }^{\mathrm{z}} \mathrm{Pic}=$ chloropicrin; $1,3-\mathrm{D}=1,3$ dichloropropene; AITC = allyl isothiocyanate; MITC = methyl isothiocyanate; f.b. = followed by

${ }^{y}$ Analysis of variance with adjunct Fisher's least significant difference test. Any two means within a row not followed by the same letter are statistically different at $P \leq 0.01$.

$\mathrm{gal} / \mathrm{acre})+66 \% \mathrm{Pic}+1,3-\mathrm{D} 60$ (27 gal/ acre) controlled weeds, $P$. ultimum, and F. oxysporum (Table 3 ). Also, in a strawberry field trial in Salinas, Pic+1,3-D (20 gal/acre) followed by AITC (20 gal/ acre) controlled $P$. ultimum, V. dabliae, as well as the citrus nematode and weeds when applied through the drip line system (Table 3). This treatment also significantly reduced weed seed viability of burning nettle, knotweed, common purslane germination, and spouting of yellow nutsedge tubers in Salinas (Table
4), and it led to significantly higher strawberry yields (Table 5). MITC (31 gal/acre) followed by AITC (20 gal/ acre) applied through the drip line also controlled soil-borne pathogens (Table 3 ) and reduced weed seed viability and nutsedge tuber germination significantly (Table 4). Our results imply that AITC stand-alone treatments under field conditions of the central coast and southern coast of California are not very efficient, while multitactic approaches can efficiently control soil- borne diseases and weeds. Higher dosages of the commonly used fumigants Pic +1,3-D or MITC are necessary to effectively control pathogens and weeds in combination with AITC, if applied via shank or drip as preplant fumigant (Bangarwa and Norsworthy 2015, 2016; Vallad and Boyd, 2013).

AITC is an oily substance with vapor pressure of $4 \mathrm{~mm} \mathrm{Hg}$ at $20^{\circ} \mathrm{C}$. The low vapor pressure of AITC leads to much slower diffusion through the water and air body in the soil, and it 
Table 5. Yield of marketable fruit from Apr. 2014 to the beginning of Aug. 2014 in Watsonville, CA, and from Apr. 2015 to the end of Sept. 2015 in Salinas, CA. No significant differences were observed between treatments in Watsonville, CA.

\begin{tabular}{llc}
\hline Location & \multicolumn{1}{c}{ Treatment $^{\mathbf{z}}$} & Marketable yield (lb/acre) $^{\mathbf{y}}$ \\
\hline Watsonville, CA & Nontreated control & $19,208 \mathrm{Ns}$ \\
& Pic+1,3-D & $22,027 \mathrm{Ns}$ \\
& AITC & $22,090 \mathrm{NS}$ \\
& Pic+1,3-D f.b. AITC (low) & $22,063 \mathrm{Ns}$ \\
Salinas, CA & Pic+l,3-D f.b. AITC (high) & $21,885 \mathrm{NS}$ \\
& Nontreated control & $60,663 \mathrm{bc}^{\mathbf{x}}$ \\
& MITC (low) & $57,480 \mathrm{c}$ \\
& MITC (high) & $62,697 \mathrm{abc}$ \\
& AITC (low) & $62,890 \mathrm{ab}$ \\
& AITC (high) & $61,261 \mathrm{bc}$ \\
& Pic+l,3-D f.b. AITC & $66,881 \mathrm{a}$ \\
& MITC f.b. AITC & $62,895 \mathrm{ab}$ \\
& Pic+l,3-D f.b. MITC & $64,620 \mathrm{a}$ \\
\hline
\end{tabular}

${ }^{\mathrm{z}} \mathrm{Pic}=$ chloropicrin; $1,3-\mathrm{D}=1,3$ dichloropropene; $\mathrm{AITC}=$ allyl isothiocyanate MITC = methyl isothiocyanate; f.b. $=$ followed by; $\mathrm{NS}=$ nonsignificant .

${ }_{1}^{\mathrm{l}} \mathrm{lb} / \mathrm{acre}=1.1209 \mathrm{~kg} \cdot \mathrm{ha}^{-1}$.

${ }^{\mathrm{x}}$ Analysis of variance with adjunct Fisher's least significant difference test. Any two means within a row not followed by the same letter are statistically different at $P \leq 0.01$

can be the main reason for the observed inconsistency in pathogen and weed control in stand-alone soil disinfestation treatments (Tables 2-4). However, other factors might have a more significant role in determining the fate and efficacy of AITC than those determined for conventional fumigants (Siebering and Leistra, 1979). Isothiocyanates are reported to have pesticide activity and can be catabolized by soil microbial processes (Di Primo et al., 2003; Price et al., 2005; Warton et al., 2001). Although every fumigant can be catabolized to a certain rate, Price et al. (2005) showed that effective AITC concentrations in the gas and liquid phases were highly dependent on soil microbial respiration and soil texture. The degradation of mustard tissue in different soil types harvested three times more AITC in sterile soil compared with nonsterile soil. According to Price et al. (2005), this indicated a certain amount of metabolic catabolism in nonsterile natural soil. Price et al. (2005) also described $38 \%$ more recovery of AITC in sandy soils compared with clay soils.

AITC as a stand-alone fumigant does not have consistent efficacy under central and southern coastal conditions in California. However, although AITC did not provide much additional control when combined with other fumigants, our results concluded that the combination of conventional fumigants with AITC led to sufficient pathogen and weed control efficacy. Combinations of AITC with mixtures of $\geq 50 \%$ Pic $+1,3-\mathrm{D}$ showed reliable and high pathogen and weed control efficacy in both shank- and drip-applied systems. Such multitactic approaches might be useful in those areas where township caps or sensitive sites limit the use of conventional fumigants.

\section{Literature cited}

Atwood, D. and C. Paisley-Jones. 2017. Pesticides industry sales and usages 2008 2012 market estimates. U.S. Environ. Protection Agency, Office Pesticide Programs, Office Chem. Safety Poll. Prev., Washington, DC.

Ayoub, S.M. 1977. Plant nematology: An agricultural training aid. Dept. Food Agr., Div. Plant Industry, Lab. Serv. State of California, Sacramento.

Baalbaki, R.Z., S.G. Elias, J. MarcosFilho, and M.B. McDonald. 2009. Seed vigor testing handbook. Contribution No. 32. Assn. Offic. Seed Analysts, Washington, DC.

Bangarwa, S.K. and J.K. Norsworthy. 2014. Purple nutsedge control with allyl isothiocyanate under virtually impermeable film mulch. Weed Technol. 28:200205.

Bangarwa, S.K. and J.K. Norsworthy. 2015. Herbicidal activity of three isothiocyanates against yellow nutsedge and their dissipation under two plastic mulches. Crop Prot. 74:145-149.

Bangarwa, S.K. and J.K. Norsworthy. 2016. Effect of phenyl, allyl, and methyl isothiocyanate on Cyperus rotundus tuber under LDPE and VIF mulch. Crop Prot. 84:121-124.
Cottrell, H.J. 1947. Tetrazolium salt as a seed germination indicator. Nature 159:748.

Daugovish, O., A. Howell, S. Fennimore, S. Koike, T. Gordon, and K. Subbarao. 2016. Non-fumigant treatments and their combinations affect soil pathogens and strawberry performance in southern California. Intl. J. Food Sci. 16:37-46.

de Souza, L.P., L.R. D'Antonio Faroni, L.M. Lopes, A.H. de Sousa, and L.H. Figueiredo Prates. 2018. Toxicity and sublethal effects of allyl isothiocyanate to Stiptophilus zeamais on population development and walking behavior. J. Pest Sci. 91:761-770.

Di Primo, P., A. Gamliel, M. Austerweil, B. Steiner, M. Beniches, I. Peretz-Alon, and J. Katan. 2003. Accelerated degradation of MITC and dazomet in soil: Characterization and consequences for pathogen control. Crop Prot. 22:635646.

Fahey, J.W., A.T. Zalcmann, and P. Talalay. 2001. The chemical diversity and distribution of glucosinolates and isothiocyanates among plants. Phytochemistry $56: 5-51$.

Fennimore, S.A., F.N. Martin, T.C. Miller, J.C. Broome, N. Dorn, and I. Greene. 2014. Evaluation of a mobile steam applicator for soil disinfestation in California strawberry. HortScience 49:1542-1549.

Grubb, C.D. and S. Abel. 2006. Glucosinolate metabolism and its control. Trends Plant Sci. 11:89-100.

Guo, M., M.P. Yadav, and T.Z. Jin. 2017. Antimicrobial edible coatings and films from micro-emulsions and their food applications. Intl. J. Food Microbiol. 263:916.

Hoffmann, M., A. Barbella, T. Miller, J. Broome, F. Martin, S. Koike, J. Rachuy, I. Greene, N. Dorn, R. Goodhue, and S. Fennimore. 2016. Weed and pathogen control with steam in California strawberry production. Acta Hort. 1156:593601 .

Hoffmann, M. and S.A. Fennimore. 2017. A soil probe system to evaluate weed seed survival in soil disinfestation trials. Weed Technol. 31:757-760.

Isagro USA. 2015. Dominus: Biopesticide for agricultural soil treatment use. Isagro USA, Morrisville, NC.

Kabir, Z., R.G. Bhat, and K.V. Subbarao. 2004. Comparison of media for recovery of Verticillium dabliae from soil. Plant Dis. 88:49-55.

Klose, S., H.A. Ajwa, S.A. Fennimore, F.N. Martin, G.T. Browne, and K.V. Subbarao. 
2007. Dose response of weed seeds and soilborne pathogens to 1,3-D and chloropicrin. Crop Prot. 26:535-542.

Komada, H. 1975. Development of a medium for quantitative isolation of Fusarium oxysporum from natural soil. Rev. Plant Protection Res. 8:114-124.

Lin, C.M., J.F. Preston, III, and C.I. Wei. 2000. Antibacterial mechanisms of allyl isothiocyanate. J. Food Prot. 63:727734.

Lopes, L.F., K. Bordin, G.H.C. deLara, F. Saladino, J.M. Quiles, G. Mecca, and F.B. Luciano. 2017. Fumigation of brazil nuts with allyl isothiocyanate to inhibit the growth of Aspergillus parasiticus and aflatoxin production. J. Sci. Food Agr. 98:797-798.

Lopes, L.F., G. Meca, K.C.P. Bocate, T.M. Nazareth, K. Bordin, and F.B. Luciano. 2018. Development of food packaging system containing allyl isothiocyanate against Penicillium nordicum in chilled pizza: Preliminary study. J. Food Process. Preserv. 42:e13436.

Maldonado, A.F.S., A. Schieber, and M.G. Gaenzle. 2015. Plant defence mechanisms and enzymatic transformation products and their potential applications in food preservation: Advantages and limitations. Trends Food Sci. Technol. 46:49-59.

Mazzola, M., A. Agostini, and M.F. Cohen. 2017. Incorporation of Brassica seed meal soil amendment and wheat cultivation for control of Macrophomina phaseolina in strawberry. Eur. J. Plant Pathol. 149:57-71.

Munnecke, D.E. and S.D. Van Gundy. 1979. Movement of fumigants in soil, dosage responses and differential effects. Annu. Rev. Phytopathol. 17:405-429.
Neubauer, C., K. Huentemann, B. Heidtmann, and C. Mueller. 2015. Suppression of Verticillium dabliae by glucosinolate-containing seed meal amendments. Eur. J. Plant Pathol. 142: 239-249.

Price, A.J., C.S. Charron, A.M. Saxton, and C.E. Sams. 2005. Allyl isothiocyanate and carbon dioxide produced during degradation of Brassica juncea tissue in different soil conditions. HortScience 40:1734-1739.

Rosskopf, E.N., J.C. Hong, N. KokalisBurelle, J. Holzinger, B. Booker, S. YatesYarbrough, and J. Sances. 2017. Dominus for cut flower production. Annu. Intl. Res. Conf. Methyl Bromide Alternatives Emissions Reductions (MBAO), San Diego, CA.

Shennan, C., J. Muramoto, S. Koike, G. Barid, S. Fennimore, J. Samtani, M. Bolda, S. Dara, O. Daugovish, G. Lazarovtis, D. Butler, E. Rosskopf, N. Kokalis-Burelle, K. Klonsky, and M. Mazzola. 2018. Anaerobic soil disinfestation is an alternative to soil fumigation for control of some soilborne pathogens in strawberry production. Plant Pathol. 67:51-66.

Siebering, H. and M. Leistra. 1979. Computer simulations of fumigant behaviour in soil. Dev. Agr. Mgt. Ecol. 6:135-161.

U.S. Environmental Protection Agency. 2010. Soil fumigation mitigation factsheet implementation schedule. U.S. Environ. Protection Agency Factsheet 738-F-10-003.
Vallad, G.E. and N. Boyd. 2013. IRF135 , an allyl isothiocyanate biopersticide for managing weeds, pests, and pathogens in soil. Annu. Intl. Res. Conf. Methyl Bromide Alternatives Emissions Reductions (MBAO), San Diego, CA.

Warton, B., J.N. Mattheissen, and N.M. Roper. 2001. The soil organisms responsible for the enhanced biodegradation of metham sodium. Biol. Fertil. Soils 34:264-269.

Wood, C., D.M. Kenyon, and J.M. Cooper. 2017. Allyl Isothiocyanate shows promise as a naturally produced suppressant of the potato cyst nematode, Globodera pallida, in biofumigation systems. Nematology 19:389-402.

Wu, H., G.A. Zhang, S. Zeng, and K.C. Lin. 2009. Extraction of allyl isothiocyanate from horseradish (Armoracia rusticana) and its fumigant insecticidal activity on four stored-product pests of paddy. Pest Manag. Sci. 65:1003-1008.

Xu, Y., R.E. Goodhue, J.A. Chalfant, T. Miller, and S.A. Fennimore. 2017. Economic viability of steam as an alternative to preplant soil fumigation in California strawberry production. HortScience 53:401407. 